\title{
Kerk en owerheid binne 'n regstaat. Die profetiese roeping van die kerk met betrekking tot die Suid-Afrikaanse owerheid
}

\author{
Nico Vorster \& J.H. van Wyk \\ Skool vir Kerkwetenskappe \\ Potchefstroomse Universiteit vir $\mathrm{CHO}$ \\ POTCHEFSTROOM \\ E-pos: amievw@intekom
}

\begin{abstract}
Church and government within a constitutional state. The prophetic calling of the church towards the South-African government

With the transition to a new political dispensation in South Africa, a constitutional state has been established. A typical characteristic of this new dispensation is that the government remains neutral while the executive powers are subject to the Bill of Human Rights. The question of how the church can realize its prophetic task towards the government within the context of a constitutional state is highlighted in this article. The central theoretical argument is that a constitutional state that acknowledges fundamental rights provides an excellent opportunity for the church to fulfil its prophetic calling within the South African context. The church can contribute to a just society by prophetic testimony within the perspective of the kingdom of God.
\end{abstract}

\section{Oriëntering}

Die oorgang tot 'n nuwe demokratiese bedeling in 1994 het gelei tot 'n verskuiwing in die verhouding tussen die owerheid en Christelike kerke. Die vorige minderheidsregering het homself as 'n voorstander van Christelike waardes beskou. Dit blyk uit die inleiding tot die 1983-Grondwet waarin gesê word dat die Konstitusie probeer om Christelike waardes te handhaaf. Die owerheid se ideaal van 'n samelewing gebaseer op Christelike waardes het daartoe gelei dat die Christelike godsdiens voorkeurbehandeling bo ander godsdienste en waardesisteme geniet het. Sodoende het die Christelike godsdiens byvoorbeeld eksklusiewe toegang tot die aanbieding van godsdiensprogramme op televisie gehad 
bo ander godsdienste. Die Wet op Publikasies (42/1974) het bepaal dat die Suid-Afrikaanse bevolking se Christelike lewens- en wêreldbeskouing in die toepassing van die wet erken sal word. Die Wet op Nasionale Onderwysbeleid (39/67) het in seksie 2(1a en b) bepaal dat wit kinders se onderrig Christelik-nasionaal sou wees, en die Wet op Onderwys en Opleiding (90/1979) het in seksie 3(a) bepaal dat swart kinders se onderrig Christelik sou wees sonder die nasionale komponent. Daar was ook 'n verskeidenheid Sondagsonderhoudingstatute en provinsiale ordonnansies wat aan die een kant betrekking gehad het op sakeondernemings en aan die ander kant op vermaak en ontspanning (vgl. Van der Vyver, 1998a:3 en die Wet op die Verbod op die Vertoon van Rolprente op Sondae en Openbare Vakansiedae 16/1977). Alhoewel dit debatteerbaar is of die owerheid met sy oënskynlike skending van basiese menseregte werklik Christelike waardes gehandhaaf het, moet gesê word dat die owerheid voorkeurbehandeling aan die Christelike godsdiens en waardesisteem gegee het, bo ander godsdienste en waardesisteme.

Met die oorgang na 'n nuwe demokratiese bedeling is ' $n$ regstaat in SuidAfrika gevestig. Die konsep van 'n regstaat dui op 'n maatstaf waarmee die gebalanseerdheid, regverdigheid en effektiwiteit van 'n bepaalde staatkundige bestel gemeet word (Venter, 1995:33). Dit dui nie op 'n vorm van regering nie, maar op die wyse waarop 'n land se regsisteem werk (Coetzee, 1995:33). Le Roux (1994:56) gee die volgende omvattende omskrywing van 'n regstaat:

Die regstaat gee erkenning aan grondwetlike regering en die oppergesag van die Reg. Dit beteken dat 'n owerheid se take deur regsvoorskrifte bepaal en afgebaken word. Terselfdertyd word die private en openbare vryhede en regte van elke individu beskerm, soos die vryheid van spraak, keuse van beweging en assosiasie sonder staatsinmenging. Die regstaat gee in 'n gedifferensieerde samelewing uitdrukking aan sowel politieke medeseggenskap deur individue as aan burgerlike owerhede. Voorts verskaf hy formele waarborge vir die verwesentliking van die regstaatbeginsel. Dit sluit in die skeiding van magte, regsbeskerming teen wanadministrasie, en onafhanklike regspraak en administrasie in ooreenstemming met die geskrewe wette van die Parlement.

Verskeie regstaatbeginsels word in die 1996-Grondwet gevind. Paragraaf 1(c) erken die oppergesag van die Grondwet, sowel as die heerskappy van die reg. Paragraaf 8(1) bepaal dat die Handves van Regte betrekking het op alle wette, en dat dit die wetgewer, die uitvoerende gesag en alle organe van die staat bind. Die uitvoerende, wetgewende en geregtelike gesag word deur die Grondwet geskei (vgl. paragrawe 165(2), 44 en 83). Kenmerkend van 'n regstaat, word die onafhanklikheid 
van die howe deur die Grondwet beskerm in paragraaf 165(2). Basiese demokratiese beginsels word beskerm in paragraaf 1 , en verder word ook voorsiening gemaak vir instellings ter beskerming van die Grondwetlike demokrasie in paragraaf 185(1).

Alhoewel die 1996-Grondwet nie soos die 1993-Interim-grondwet uitdruklik na Suid-Afrika as 'n regstaat verwys nie, word dit uit bogenoemde gegewens duidelik dat Suid-Afrika 'n regstaat is wat probeer breek met 'n totalitêre verlede. Die beginsels en belangrikste elemente inherent aan 'n regstaat is in die finale grondwet opgeneem in 'n direkte opdrag aan die grondwetskrywende vergadering (Venter, 1997:75). Venter (1997:81) wys ook op die feit dat die Konstitusionele Hof alreeds in 1996 verwys het na die regstaatbeginsel as die leidende beginsel vir die 1996Grondwet.

Die totstandkoming van 'n regstaat in Suid-Afrika het implikasies vir die verhouding tussen kerk en owerheid. Die Grondwet maak as die hoogste wet in Suid-Afrika nie voorsiening vir 'n politieke bestel met teokratiese elemente nie, maar wel vir 'n neutrale staat. Uit artikels 15(2) en 185(1b) van die 1996-Grondwet kan dit byvoorbeeld afgelei word dat alle godsdienste deur die owerheid op 'n gelyke voet behandel moet word. Die realiteit word weerspieël in die feit dat die owerheid nie meer uit hulle pad gaan om Christelike samelewingswaardes te handhaaf nie. So het die owerheid aborsie op aanvraag, pornografie en dobbelary gewettig. 'n Verskuiwing in die verhouding tussen kerk en owerheid het dus plaasgevind. Die kerk moet sy profetiese roeping tot die owerheid nou binne 'n regstaat uitleef waarin alle godsdienste op 'n gelyke voet met ander godsdienste behandel word, en waar die owerheid homself as 'n neutrale owerheid sien. Die vraag wat in hierdie artikel ter sake kom, is die volgende: hoe moet die kerk sy profetiese roeping met betrekking tot die owerheid binne die konteks van 'n regstaat uitleef?

Om die vraag te beantwoord sal aandag gegee word aan die volgende aspekte:

- Die belangrikste twee denklyne binne die gereformeerde tradisie oor die profetiese roeping van die kerk.

- 'n Prinsipiële uitgangspunt vir die profetiese roeping van die kerk.

- Die verstaan van artikel 36 NGB en artikels 28 en $30 \mathrm{KO}$ binne die konteks van 'n regstaat.

- Konkrete riglyne vir die uitvoering van die profetiese taak van die kerk binne die konteks van 'n regstaat. 
Vervolgens word gefokus op die twee belangrikste denklyne binne die gereformeerde tradisie oor die profetiese roeping van die kerk.

\section{Die Kuyperiaanse en Barthiaanse sienings van die profetiese roeping van die kerk}

\subsection{Die Kuyperiaanse beskouing}

In die sentrum van Kuyper se teologie staan die dialektiese verhouding tussen die algemene genade en die partikuliere genade (Velema, 1989: $69)$. Kuyper se siening van die verhouding tussen die algemene genade en die partikuliere genade bepaal dan ook tot 'n groot mate sy siening van die verhouding tussen kerk en owerheid (vgl. Kuyper, 1932? II:634). Die algemene genade gaan by Kuyper die partikuliere genade vooraf (Kuyper, 1932? II:635). Die algemene genade vind sy grond in die verbondsluiting met Noag. Die verbondsluiting met Noag is bedoel vir alle mense en het niks te doen met die saligmakende genade van God nie. Die doel van die verbondsluiting is om bestendigheid te bring aan God se skepping wat in sonde geval het (vgl. Kuyper, 1932? I:14). Deur sy algemene genade hou God die sonde in bedwang en maak Hy die menslike ontwikkelingsgeskiedenis moontlik (Van Rooyen, 1964:14). Die instelling van die owerheid, ook heidense owerhede, kom voort uit die algemene genade van God en nie uit die partikuliere genade nie (vgl. Kuyper 1932? II:161). Die doel van die algemene genade is ook die doel van die owerheid - dit is om die deurwerking van die sonde te stuit (Van Rooyen, 1964:20). Die owerheid is dus nie 'n natuurlike instelling wat uit die volk voortkom nie, maar wel 'n teennatuurlike instelling van God iets wat nodig is weens die sondige toestand van die mensheid (Kuyper, 1932? I:81).

Terwyl die owerheid uit die algemene genade voortkom, spruit die kerk voort uit die partikuliere genade. Die algemene genade bied deur sy teenwerking van die sonde ruimte vir die partikuliere genade en maak die mens vatbaar vir die evangelie. Die partikuliere genade werk terselfdertyd positief in op die algemene genade deur die gemeente (vgl. Kuyper, 1932? II:683 en Velema, 1989:65). Die kerk en die owerheid vind sy eenheid alleen in die feit dat Christus die Skeppingsmiddelaar is, juis omdat die verenigingspunt tussen die algemene genade en die partikuliere genade vir Kuyper in die Skeppingsmiddelaarskap van Christus lê (vgl. Kuyper, 1932? III:123). Die kerk en owerheid moet egter in beginsel onderskeie bly, omdat "de staat zijn oorsprong heeft uit de gemeene gratie, de kerk in de partikuliere genade" (Kuyper, 1932? III:107). Die owerheid het immers te doen met die burgerlike lewe terwyl die kerk te doen het met die sondaarmens se inwendige lewe; die 
owerheid gebruik 'n uiterlike mag en sy roeping lê in die hede, terwyl die kerk 'n geestelike mag het, en sy einddoel in die ewigheid lê (Kuyper, 1932? III:113-121).

Maar as die kerk nie mag inmeng in die sfeer van die owerheid nie, hoe moet die kerk dan die staatkundige lewe beïnvloed? Kuyper probeer die probleem oorkom met sy onderskeiding tussen die kerk as organisme en instituut. Die organisme en instituut is volgens Kuyper die tweërlei bestaansvorm van die ecclesia visibilis (1909 III:204). Die kerk as organisme gaan die kerk as instituut vooraf. Die organisme is die hart van die kerk waaruit die polsslag en lewensbloed van die kerk kom (vgl. Kuyper, 1870:8). Die instituut word uit die organisme gebore, maar die organisme word terselfdertyd deur die instituut gevoed deur die bediening van die Woord (vgl. Kuyper, 1870:15). Die instituut is die amptelike formasie van die gelowiges, en het die roeping om die Woord en die sakramente te bedien (Kuyper, 1909 III:215,228). Die doel van die organisme is om soos ' $\mathrm{n}$ lig die Woord van God in die samelewing uit te straal (vgl. Kuyper, 1932? II:272).

Die kerk as instituut kan volgens Kuyper nie 'n direkte invloed op die samelewing uitoefen nie, omdat die instituut se roeping beperk is tot die bediening van die Woord aan die besondere gemeenskap van gelowiges. Alleen die organisme kan op 'n sydelingse manier invloed uitoefen op die verskillende samelewingskringe (vgl. Kuyper, 1909 III: 204). Die gevolg van hierdie siening van Kuyper is dat hy min maak van amptelike uitsprake van die kerk met betrekking tot die samelewing. Daar is by Kuyper nie eintlik sprake van 'n profetiese taak van die kerk in sy amptelike gestalte jeens die owerheid nie. Hy lê wel baie klem op die Christelike organisasie, waardeur die kerk as organisme in die wêreld sigbaar word (vgl. Strauss, 1993:12). Die gevolg hiervan is dat hy die profetiese taak van die kerk aan die Christelike organisasie opdra. Die Christelike politieke party wat vir Christelike norme veg word die profetiese mondstuk van die kerk.

Kuyper se siening het 'n ingrypende invloed uitgeoefen op die Gereformeerde tradisie in Suid-Afrika. Dooyeweerd het in sy samelewingsleer filosofies voortgebou op die ekklesiologiese onderskeidinge van Kuyper (Vorster, 1997a:182). Stoker het op sy beurt weer in Suid-Afrika met die Wysbegeerte van die skeppingsidee voortgebou op Dooyeweerd (Strauss, 1993:13). Die siening van die GKSA oor die profetiese roeping van die kerk is in die praktyk ook hoofsaaklik deur die Kuyperiaanse denklyn beïnvloed. Vorster (1993a:216) wys daarop dat die Kuyperiaanse denklyn homself manifesteer op Gereformeerde kerklike vergaderings in 'n bepaalde interpretasie van artikel $30 \mathrm{KO}$, waarvolgens "kerklike sake" verstaan word as sake wat alleen met die kerklike 
instituut en gemeenskap van gelowiges te doen het. Ook Van Wyk (1991a:180-181) wys op die feit dat die Kuyperiaanse onderskeid tussen die kerk as instituut en organisme in die GKSA dikwels verabsoluteer is.

Kuyper se siening oor die profetiese roeping van die kerk skep meer probleme as wat dit antwoorde gee. Velema (1989:69) wys tereg op die feit dat Kuyper deur sy siening van die dialektiese verhouding tussen die algemene en partikuliere genade idealistiese denke in sy teologie invoer. Vanuit hierdie onderskeiding bou Kuyper ' $n$ idealistiese samelewingsleer met dualistiese trekke uit. Hy gee aan die algemene genade 'n selfstandige doel en 'n progressiewe ontplooiende betekenis, en gebruik die begrip sodoende om 'n omvattende kultuurbeskouing uit te bou. In teenstelling hiermee gebruik Calvyn die begrip net om aan te dui hoe God die skepping van totale ineenstorting weerhou (vgl. Wentsel, 1982:229). Deur sy onderskeiding tussen die kerk as organisme en instituut, skei Kuyper die organiese en institutêre aspekte van kerkwees op 'n dualistiese wyse van mekaar. Deur die instituut se taak te beperk tot die Woordbediening aan die gemeenskap van die gelowiges, verloën hy die belydende en strydende taak van die amptelike gemeenskap van gelowiges in die wêreld as 'n gestalte van die koninkryk. Van die amptelike profetiese taak van die kerk in die wêreld kom daar in sy denke niks tereg nie. Hy gebruik die Christelike politieke party, wat 'n manier van isolement en kragmonstering binne 'n geïsoleerde kring is, om die kerk buite die samelewing te hou. Hy hou nie net die kerk sodoende buite die samelewing nie, maar hy laat ook so toe dat ander politieke partye aan sekularisasie oorgegee word. Die negatiewe invloed van Kuyper se denke kan gesien word in die wyse waarop die GKSA hul weerhou het van amptelike kommentaar op die "apartheidsbeleid".

\subsection{Die Barthiaanse siening}

Barth se siening oor die profetiese roeping van die kerk met betrekking tot die owerheid moet verstaan word teen die agtergrond van sy verset teen 'n natuurlike teologie, asook die Christosentriese aard van sy teologie. Weens sy verset teen die natuurlike teologie en sy Christosentriese interpretasie van die werklikheid, fundeer hy die owerheid nie soos Kuyper in die algemene genade nie, maar wel in die Christologie. Barth se Christologiese fundering van die owerheid lei daartoe dat hy sowel kerk as owerheid in diens van verkondiging stel, en dat hy dus baie meer maak van die amptelike profetiese roeping van die kerk.

Barth verstaan onder die natuurlike teologie enige teologie wat nie sy uitgangspunt neem in die openbaring in Christus nie, maar wel sy data verkry uit die rede, natuur en geskiedenis (vgl. Barth, 1946:77). Hy verset homself teen enige vorm van natuurlike teologie, wat glo dat God 
Homself in historiese gebeurtenisse openbaar, omdat hierdie vorm van teologie die regerende politiese sisteme van die tyd onkrities aanvaar. Hieraan was sowel die Rooms-Katolisisme as die liberale Neo-Protestantisme, wat uit die volgelinge van Schleiermacher bestaan het, skuldig (Küng, 1995:191, 192). Hy het hom ook verset teen die vorm van natuurlike teologie wat teoloë soos Brünner en Kuyper bedryf het, waarvolgens die algemene genade 'n voorbereidende genade vir die saligmakende genade sou wees, en as 'n punt van kontak tussen God en mens dien. Hierdie siening verraai volgens Barth die beginsels van sola fide en sola gratia. Die mens is totaal in sonde gevalle. Geen natuurlike kennis bly in die mens oor na die sondeval nie (vgl. Brünner \& Barth, 1946:90).

Barth fundeer die owerheid teologies in die oorwinning van Christus oor alle bose magte. Omdat Christus alle bose magte oorwin het, word alle magte en kragte nou aan Hom onderwerp. Uit Kolossense 2:15 blyk dit nou volgens hom dat hierdie magte tot diens en verheerliking van Christus gebruik word as 'n openlike teken van die triomf van Christus oor al die bose magte (Barth, 1944:16). Die gevolg van Barth se Christologiese fundering van die owerheid is dat hy aan sowel kerk as owerheid 'n Goddelike mandaat gee, gegrond in die herskeppende werk van Christus. Kerk en owerheid val vir hom binne die verbondshandelinge van God. So deurbreek hy enige vorm van die tweeterreineleer. Sowel kerk as owerheid funksioneer binne die sfeer van die evangelie, omdat die wet 'n vorm van evangelie is. Dit bring hom uit by die punt waar hy kan praat van 'n analogiese verhouding tussen kerk en owerheid.

Om die verhouding tussen kerk en staat te verduidelik gebruik Barth die beeld van twee konsentriese sirkels. Die Christengemeinde vorm die binnenste sirkel en die Bürgergemeinde vorm die buitenste sirkel. Die gemeenskaplike binnepunt van die twee sirkels is Jesus Christus en die verkondigde koninkryk (vgl. Strauss, 1993:18 en Durandt, 1988:129). Elkeen van hierdie twee sirkels is deel van die ryk van Christus (Barth, 1946:11). Die twee konsentriese sirkels mag nie in mekaar opgeneem word nie. Elke sirkel het sy eie opdrag. Die Christengemeinde moet die heerskappy van Christus verkondig, vir die staat bid en die Bürgergemeinde herinner aan die koms en wederkoms van Christus (1946:21). Die Christengemeinde mag egter self nooit politiek probeer bedryf nie (1944:33). Die taak van die Bürgergemeinde is op sy beurt nie Woordverkondiging nie, maar wel om 'n spieëlbeeld van die koninkryk van God te wees deur die ordeninge van God te respekteer en as bindend te beskou (vgl. 1946:13, 22). 
Die verhouding tussen kerk en staat is dus vir Barth analogies van aard. Die lig van die koninkryk val op die kerk, die kerk straal deur die Woordverkondiging die lig op die staat uit, en die staat kan nie anders as om hierdie lig te weerkaats en te weerspieël nie (Strauss, 1993:19). Die regte staat vind sy grond in die kerk: "Der rechte Staat muss in der rechte Kirche sein Urbild en Vorbild haben" (Barth, 1946:33). Die kerk is dus 'n eksemplariese gemeenskap wat Bybelse voorskrifte in 'n analogiese vorm aan die staat deurgee deurdat die kerk 'n sigbare bewys word van die dade van Christus (Barth, 1962:724). Die Christelike gemeenskap sal daarom altyd vir 'n regverdige staat kies, en hulleself altyd beywer vir die armes en die swakkes (Durandt, 1988:130).

Dit is vir Barth belangrik dat daar 'n kritiese afstand tussen kerk en staat moet bestaan. Hy verset hom daarom heftig teen die idee van 'n Christelike politieke party. 'n Christelike party is onnodig, want die Christelike kerk het 'n besondere opdrag van God ontvang wat oor die hele politieke spektrum strek (1946:37). Die taak van die kerk is nie om op die politieke gebied sigbaar te word nie, maar wel om as 'n spieël vir die staat te dien (1946:37). Op politieke gebied kan die Christen "nur anonym auftreten" (1946:38). Net wanneer die Christen direk vir die belange van die kerk moet stry, kan hy hierdie anonimiteit deurbreek (1946:38). So wil Barth keer dat die Christelike boodskap gekompromitteer word.

Terwyl die Christen op politieke gebied alleen anoniem kan optree, lê Barth baie klem op die profetiese taak van die kerk deur amptelike vergaderinge. Dit word weerspieël deur die volgende aanhaling uit Christengemeinde und Bürgergemeinde:

Die Christengemeinde handelt auch dann im Sinn und in den Grenzen ihres Auftrags und ihrer Kompetenz, wenn sie durch den Mund ihrer presbyterialen und synodalen Organe in wichtigen Situationen des politischen Lebens durch besondere Eingaben an die Behörden oder durch öffentliche Proklamationen sich zu Worte meldet (1946: 40).

Die anominiteit van die Christen in die politiek word so vervang deur die sigbaarheid van die kerk wat predik, waaruit die gelowiges die implikasies verstaan (Durandt, 1988:130).

Barth se teologie het gedurende die sestiger- en sewentigerjare inslag begin vind onder jong Afrikaanse teoloë, waarvan Beyers Naudè die bekendste was (Durandt, 1988:122). In die tagtigerjare het Barth se invloed in die NGK begin toeneem. In 1982 is 'n ope brief wat sterk Barthiaanse aksente gedra het, deur honderd-drie-en-twintig ondertekenaars aan die NGK gerig. Die Barthiaanse invloed kan gesien word in die brief se beskrywing van die kerk as 'n "proeftuin" van God vir die 
wêreld wat as 'n voorbeeld van eenheid, liefde en geregtigheid moet dien (vgl. Strauss, 1993:23 en Durandt, 1988:134). Heyns en Jonker was twee prominente teoloë binne die NGK wat in die tagtiger- en negentigerjare Barthiaanse denke begin openbaar het. Strauss (1993: 24, 25) wys daarop dat Heyns begin praat het van die kerk as 'n "voorbeeldige gemeenskap", terwyl Jonker hom verset het teen enige vorm van "skeppingsteologie" en ook baie klem op die Christologie begin lê het. Strauss $(1993: 19,23)$ kom tot die gevolgtrekking dat Kerk en samelewing (1990) sterk Barthiaanse elemente dra, veral weens die invloed van Heyns. Binne die GKSA het die siening van Barth nog nie 'n direkte invloed uitgeoefen nie, moontlik weens 'n verset teen sy Skrifbeskouing. Daar is wel heelwat teenkanting teen Kuyper se siening van die profetiese taak van die kerk (vgl. Van Wyk, 1991a:180 en Vorster, 1993:225, 226). Die GKSA se amptelike definisie van die profetiese taak van die kerk is meer Barthiaans as Kuyperiaans (vgl. GKSA, 1970:63). In praktyk het die GKSA egter deur 'n verkeerde interpretasie van die begrip "kerklike sake" sake soos apartheid Kuyperiaans gehanteer.

Barth bied belangrike insigte vir die profetiese roeping van die kerk. Sy klem op die feit dat daar nie 'n assimilasie tussen kerk en owerheid moet wees nie, maar wel 'n kritiese afstand, is 'n belangrike beginsel. Hy maak dit ook vir die kerk moontlik om aan die een kant 'n profetiese stem te laat hoor, en aan die ander kant 'n noodsaaklike afstand te hou, deur sy klem op die feit dat meerdere vergaderings hulself profeties tot die owerheid moet rig. Nog 'n positiewe aspek van sy denke is dat hy nie 'n totale skeiding tussen kerk en owerheid bepleit nie, maar dat hy ook die owerheid as 'n dienaar in God se koninkryk sien. Verder verdien sy nadruk op die regte van armes en die noodsaak van 'n regstaat lof. Barth se siening skep egter ook probleme.

Dit is 'n ope vraag of Barth se idee dat die samelewing noodwendig die kerk se voorbeeld sal volg, nie idealisties is nie (vgl. ook Durandt, 1988:34). Sy idee dat die Christen op die gebied van die politiek alleen anoniem kan optree, skep ook probleme. Die vraag is: hoe bevorder die Christen Christelike waardes in die samelewing deur anoniem op te tree? Die Christen sal as hy anoniem moet optree, een of ander aansluitingspunt met die sekulêre wêreld moet vind, en hiervoor maak Barth se teologie geen voorsiening nie, omdat hy die leer van die algemene genade verwerp. 


\section{3. 'n Prinsipiële uitgangspunt vir die profetiese roeping van die kerk met betrekking tot die owerheid}

\subsection{Ou-Testamentiese perspektiewe}

Die verhouding tussen kerk en owerheid behoort vanuit die perspektief van die koninkryk benader te word. Die kerk het in die uitvoering van sy profetiese roeping die koninkryk van God as rigpunt. Die kerk is daar ter wille van die koninkryk en stel die koninkryk aan die wêreld voor (Van Wyk, 1991b:286). Alhoewel die begrip koninkryk nie in die Ou Testament voorkom nie, maak die Ou Testament baie van die koningskap van Jahwe. Volgens Ridderbos (1969:4) onderskei die Ou Testament tussen ' $n$ algemene en 'n besondere vorm van koningskap van Jahwe. Die algemene koningskap van Jahwe het te doen met sy universele heerskappy oor die hele wêreld, en is gegrond in die feit dat Hy die hele skepping geskape het. Sy besondere koningskap dui op die besondere verhouding wat daar tussen Hom en Israel was. Jahwe se besondere vorm van koningskap oor Israel word uitgedruk deur die teokrasie. Met teokrasie word bedoel dat Israel 'n gemeenskap was wat direk deur God geregeer is. Die militêre, wetgewende en geregtelike gesag was in die hande van Jahwe (Macleod, 1988:677). Die koning het namens Jahwe geregeer, hy moes God se gevegte veg en hy mag nooit vergeet het dat Jahwe die eintlike Koning is nie (vgl. Deuteronomium 17:15; 2 Samuel 8:5-20). Die volk was 'n teonome volk wat direk onder die wet van God geleef het. Die dekaloog het 'n Goddelike oorsprong gehad, en ongehoorsaamheid aan die Israelitiese wette was ook ongehoorsaamheid teenoor God, en het tot Goddelike oordeel gelei (vgl. Eksodus 22:24). Die Israelitiese teokrasie was hoofsaaklik gevestig op die idee van die verbond, wat Israel gestempel het as God se volk wat deur God uitverkies is, wat direk deur God geregeer word, en direk onder die wet van God leef. Die verbond hang ten nouste saam met die koninklike heerskappy van God, omdat die verbond (beriet) 'n uitdrukking is van God se dinamiese heerskappy oor sy volk (malkoet).

Daar kan nie vanaf die Israelitiese teokrasie 'n kontinue lyn na die moderne samelewing getrek word nie. Die Israelitiese teokrasie was 'n unieke verskynsel gegrondves op God se uitverkiesing en sy verbond. Die moderne samelewing kan nie volgens teokratiese voorskrifte geregeer word nie. Daar is egter wel 'n bepaalde kontinuïteit tussen die Nuwe-Testamentiese kerk en die teokrasie. Paulus sien die kerk as die voortsetting en vervulling van die historiese verbondsvolk van God wat die Here uit die geslagte uitverkies het en deur sy verbondsluiting aan Hom gebind het (Ridderbos, 1966:363). Die kerk toon al die eienskappe van die teokrasie. Die kerk is die verbondsvolk van God. Christus is die Hoof van die kerk (Ef. 4:15). Hy rus die gelowiges toe vir hulle taak deur 
ampte aan die kerk te gee (Ef. 4:11). Hy gee deur die Gees gawes aan die kerk (1 Kor. 12:1-5). Dissipline word in sy Naam uitgeoefen (1 Kor. $5: 4$ ). Hy tree as verbondsmiddelaar tussen God en sy volk op (Rom. 8:33 en 34).

In die Israelitiese teokrasie word alreeds 'n koninkryksperspektief gevind, omdat die verbond (beriet) 'n noue verband toon met God se dinamiese koningsheerskappy (malkoet). Die profete verkondig ook die dag waarop Jahwe Homself duidelik as 'n Koning oor die hele wêreld sal bewys en 'n Messiaanse koninkryk op aarde gevestig sal word (vgl. Jesaja 40:10, 11:49 en Daniël 2:44).

\subsection{Nuwe-Testamentiese perspektiewe}

Die Nuwe-Testament teken Christus as die Kurios oor die hele skepping, ook die kerk en owerheid (vgl. Kolossense 1:16-20 en Efesiërs 1:20-23). Kerk en owerheid kan dus nie op 'n absolute wyse van mekaar geskei word nie, omdat sowel kerk as owerheid in diens van die koninkryk van God staan. Elkeen het egter 'n eiesoortige aard, funksie en fundering binne die koninkryk van God. Die kerk staan in 'n geestelike en geloofsverbondenheid met God en medegelowiges (Du Plooy, 1991: 105). Dit is die volk van die koninkryk van God wat die besondere gesagsfeer van Christus is, en wat as 'n instrument van die koninkryk van God die koningsheerskappy van God aan die wêreld moet verkondig. In Matteus 16:18 en 19 ontvang die kerk die sleutels van die koninkryk van God. Die sleutels dui op die volmag wat die kerk het om God se oordeel oor ongelowiges en die vergewing van sondes aan gelowiges te verkondig. Dit gaan dan hier oor die bediening van die Woord en tug (HK, Sondag 31). Volgens Ridderbos (1969:362) gaan dit oor juridiese gesag wat op aarde uitgeoefen word en in die hemel bevestig word. Uitwerping uit die koninkryk dui op uitwerping uit die kerk en omgekeerd. Die futurum perfektum passiewe perifrastiese konstruksie in vers 19 dui op die feit dat dit hier gaan oor die uitvoering van besluite wat alreeds in die hemel geneem is.

In Matteus 28:18-20 ontvang die apostels hul sendingopdrag. Die sendingopdrag is egter nie net tot die apostels beperk nie, omdat die apostels hier as verteenwoordigers van die nuwe Israel optree (Ridderbos, 1969:374). Die besondere belang van die sendingopdrag is dat dit net voor die hemelvaart gegee word. Die feit dat Christus nou as Kurios oor hemel en aarde heers, het kosmologiese implikasies. Die kerk word die medium waardeur die Heilige Gees die kultuur vernuwe, sondige politieke sisteme gevange neem en die werking van die sonde op alle terreine teengaan. Die Christelike godsdiens mag nie deur die owerheid 
uit die openbare lewe geweer word nie, omdat die kerk die instrument is waardeur God sy koninkryk aan die wêreld proklameer.

Terwyl die kerk ' $n$ geloofsgemeenskap is, is die owerheid ' $n$ juridiese gemeenskap wat sy bestemming vind in die handhawing van reg in 'n gemeenskap van mense wat volgens gemeenskaplike regsreëls binne 'n bepaalde grondgebied leef (vgl. Du Plooy, 1991:106). Romeine 13:1-7 bring die owerheid en koninkryk in verband met mekaar. Die gedeelte kom voor binne 'n omvattende paranese wat vanaf Romeine 12-15:13 strek. Romeine 13: 1-7 is 'n kleiner paranetiese gedeelte binne die groter paranese waarin gelowiges opgeroep word om ook ten opsigte van die owerheid die wil van God uit te voer. Ons vind hier nie 'n teologiese uiteensetting oor die staat nie, maar wel 'n paranese gerig vanuit en gefundeer in God (Venter, 1985:104). Hierdie teologiese gerigtheid en grond het volgens Venter (1985:104) 'n dubbele dimensie, naamlik dat God aan die owerheid gesag gee in sy verhouding tot mense, maar in sy verhouding tot God is die owerheid 'n dienaar. In vers 2 word die owerheid beskryf as ' $n$ instelling van God, en in vers 4 word gepraat van die swaardmag van die owerheid. Maxaira dui hier volgens Rienecker en Rogers (1980:378) op die uitvoerende en kriminele jurisdiksie van die owerheid om te straf. God gee dus aan die owerheid die mag om reg en orde te handhaaf (Ridderbos, 1959:54). In sy verhouding tot mense het die owerheid gesag, maar in sy verhouding tot God is die owerheid 'n dienaar. In vers 4 word die owerheid twee maal die diakonos van God genoem, en in vers 6 word die owerheid ook die leitourgoi van God genoem. Volgens Venter (1997:29) vorm hierdie uitdrukkings 'n omramingspatroon vanaf vers 4-6 en beklemtoon dit die feit dat alles wat in hierdie verse staan, gesien moet word vanuit die perspektief dat die owerheid 'n dienaar van God is. Die dienaarskap van die owerheid word in vers 4 op twee vlakke gestel naamlik dat die owerheid "dienaar van God jou ten goede is" en dat die owerheid 'n "dienaar van God [is], 'n wreker om die wat kwaaddoen te straf".

Uit die voorafgaande is dit dus duidelik dat Paulus die owerheid nie losmaak van die koninkryk van God nie, maar dat hy aan die owerheid 'n integrale plek binne die koninkryk van God toeken. Van Wyk (1992:558) wys tereg daarop dat die koninkryk alle aardse ryke relativeer en relateer. Aardse koninkryke mag nie 'n bestaan los van die koninkryk van God voer nie, maar hulle moet diensbaar wees aan die koninkryk van God. Die kerk sal daarom - as 'n instrument van die koninkryk van God - die owerheid voortdurend aan sy Godgegewe plek binne die koninkryk van God moet herinner, naamlik dat die owerheid reg en orde moet handhaaf, sodat die evangelie sy vrye gang kan gaan, en sodat die kerk 
met vryheid die sleutels van die koninkryk kan gebruik en sy sendingopdrag kan volvoer.

Die feit dat die nuwe Suid-Afrikaanse owerheid 'n neutrale owerheid is, hef nie die feit op dat die owerheid nog steeds 'n dienaar van God se koninkryk is wat reg en orde moet handhaaf nie. De Kruijf (1994:236241 ) is van oordeel dat die kerk in 'n liberale demokrasie nie 'n staande profetiese taak het nie, maar dat die kerk slegs in hoogs uitsonderlike gevalle profeties teenoor die owerheid kan getuig. Die kosmiese implikasies van die koninkryksperspektief hou egter in dat die kerk binne 'n regstaat steeds 'n profetiese roeping teenoor die owerheid het. Met die koninkryk van God as uitgangspunt word die profetiese taak van die kerk met betrekking tot die owerheid in hierdie artikel só verstaan: die taak van die kerk as belydende geloofsgemeenskap is om die kosmiese dimensie van God se koningskap te proklameer en te demonstreer. Binne die perspektief van God se koninkryk moet die owerheid aan sy Godgegewe taak tot die handhawing van reg en orde herinner word, deur middel van getuienis, gesprek en belydenis (vgl. HK 48). Die inhoud van die getuienis behels nie die verkerkliking van die owerheid nie, maar wel die oproep tot die owerheid om sy eiesoortige taak as dienaar van God se koninkryk na te kom.

\section{Konfessionele en kerkordelike perspektiewe}

\subsection{Artikel 36 NGB}

Die nuwe Suid-Afrikaanse konteks van 'n regstaat met 'n neutrale owerheid wat alle godsdienste op 'n gelyke voet behandel, plaas die relevansie van artikel 36 NGB opnuut in die brandpunt. Die vraag is of artikel 36 toepasbaar is binne die nuwe konteks van 'n regstaat. Die oorspronklike formulering toon 'n duidelike teokratiese ideaal, wat toegeskryf kan word aan De Brès se verset teen die Wederdopers, en die invloed van Calvyn se bibliokratiese siening van die verhouding tussen kerk en owerheid op De Brès (vgl. Calvyn, 4.11.16 in Calvyn, 1992; Leith, 1989:199; Jonker, 1994:84 en Vorster, 1998:7).

Met die 1973 Sinode dien D.C.S. Van der Merwe opnuut 'n beswaarskrif in teen die Afrikaanse vertaling van artikel 36, nadat hy reeds by die sinode van 1970 ook 'n beswaarskrif ingedien het. Sy beswaar is sowel formeel as materieel. Sy formele beswaar is dat die Afrikaanse vertaling van 'n Latynse teks kom wat nie amptelik op die Sinode van Dordrecht van 1618 en 1619 goedgekeur is nie. Sy materiële beswaar is dat die Afrikaanse vertaling nie die inhoud van die belydenis suiwer weergee nie. Die huidige Afrikaanse vertaling sou aan die owerheid 'n viervoudige amp gee wat nie in die oorspronklike taal voorkom nie (GKSA, Acta, 
1973:191). Sy probleem is dat die woord "om" twee maal gebruik word, wat bogenoemde misverstand laat ontstaan. Volgens hom gaan dit in die oorspronklike taal oor 'n tweërlei taak van die regering, naamlik burgerlike regering en die beskerming van die kerk. Wat daarop volg, is dan die doel van die uitvoering van die take (GKSA, Acta 1973:192). Ons vind dus nie in artikel 36 'n viervoudige omskrywing van die taak van die regering nie.

Die 1979 Sinode handhaaf na studie die beswaarskrif van Van der Merwe. Die nuwe vertaling lui soos volg:

En dit is nie alleen hulle taak om aan die staatsbestuur aandag te gee en daaroor te waak nie, maar ook om die heilige Woordbediening te beskerm, om sodoende alle afgodery en valse godsdiens teen te gaan en uit te roei, die ryk van die antichriste te vernietig en die koninkryk van Jesus Christus te bevorder, die Woord en evangelie orals te laat verkondig, sodat God deur elkeen geeër en gedien word soos Hy in Sy Woord beveel.

Vorster (1993b:313) bevraagteken die idee dat die wysiging deur die GKSA slegs 'n wysiging is van die oorspronklike vertaling. Ook Polman (s.a:284) bevraagteken hierdie tipe siening. Hy beskuldig Visscher wat 'n beskouing in ooreenstemming met dié van Van der Merwe gehuldig het, van 'n onhistoriese interpretasie. Hy wys daarop dat Calvyn, Beza en De Brès se siening oor die taak van die owerheid duidelik in ooreenstemming was met die idee dat die owerheid die erediens met die swaard moes beskerm (Polman, s.a.:285). Die probleem met Van der Merwe en die Sinode van 1979 se standpunte is dat hulle op tegniestaalkundige sake fokus sonder om op die geskiedenis en die welbekende standpunte van persone soos Calvyn en De Brès te fokus. Dit kom op 'n fundamentalistiese vorm van interpretasie neer.

Die uiteindelike vraag moet egter nie wees of die nuwe formulering met die oorspronklike formulering ooreenstem nie, maar wel of die formulering Skriftuurlik getrou is. In die lig van die voorafgaande prinsipiële hoofstuk kan bevestigend hierop geantwoord word. Die artikel se herformulering slaag daarin om met ' $n$ teokratiese ideaal te breek, en rekening te hou met die oorgang vanaf die Ou-Testamentiese teokrasie na die Nuwe-Testamentiese kerk. Dit beskryf eerder die owerheid se taak teenoor die kerk as teenoor die valse godsdienste en beklemtoon só die Godgegewe taak van die owerheid as 'n instelling van God. Die eie terreine van kerk en owerheid word deur die nuwe formulering gehandhaaf, en dien as 'n belangrike korreksie op die ou formulering se ineengevlegde siening van kerk en owerheid. Die nuwe formulering is 
daarom by uitstek toepasbaar binne 'n regstaat, omdat dit die eie terreine van die kerk en owerheid handhaaf.

\subsection{Kerkordelike perspektiewe}

Artikels 28 en 30 is in die verlede op 'n problematiese wyse deur Gereformeerde meerdere vergaderings gehanteer. Artikel 30 is dikwels los van artikel 28 geïnterpreteer, en ten koste van artikel 28 beklemtoon (Van Wyk, 1991a:180). Artikel 28 is gebruik om oor mikro-etiese sake soos byvoorbeeld Sondagsonderhouding en bonusobligasies met die owerheid te praat. Makro-etiese sake wat veral politiese konsekwensies gehad het, is egter volgens artikel $30 \mathrm{KO}$ van kerklike tafels weggekeer, omdat alleen kerklike sake op 'n kerklike tafel sou tuishoort.

Artikel 28 reël dat kerklike vergaderings korrespondensie met die owerheid moet onderhou om die nodige medewerking van die owerheid te verkry. Gewoonlik wys streeks-/nasionale sinodes deputate vir korrespondensie met die owerheid aan (Spoelstra, 1989:168). Die deputate is dan die middel waardeur kerke hulself tot die owerheid kan wend, en die owerhede kan terselftertyd ook deur die deputate met kerke in gesprek tree (vgl. Nauta, 1971:461). Die deputate vir gesprek met die owerheid is volgens artikel 49 van die Kerkorde gebonde aan 'n welomskrewe opdrag van ' $n$ meerdere vergadering. Dit het dus geen selfstandige handelingsbevoegdheid nie, maar kan slegs in opdrag van die meerdere vergadering optree. Die deputate moet van al sy handelinge notule hou en aan die betrokke meerdere vergadering verslag doen (vgl. Nauta, 1971:46 en artikel 49 Kerkorde). In die geval van die deputate vir gesprek met die owerheid is daar veral drie opvallende opdragte wat telkens deur die Nasionale Sinode aan die deputate opgedra word:

- dat die deputate in die lig van genome sinodebesluite en die Kerkorde aandag moet gee aan sake wat na die deputate verwys word;

- tweedens dat die deputate wetgewing voortdurend moet dophou en in die lig van sinodebesluite moet optree, en

- derdens dat gesprekke met parlementslede/streeksverteenwoordigers gereeld moet plaasvind (vgl. GKSA, Acta, 1997:857).

Dit is juis die opdrag aan die deputate om wetgewing voortdurend dop te hou wat probleme skep. Dit is 'n ope vraag wat deputate te doen staan as wetgewing aangeneem word waaroor die sinode nie besluite geneem het nie, en hierdie wetgewing wel dringende etiese besinning vereis. Met die volgende sitting van die sinode sou die wetgewing al lankal goedgekeur of afgekeur gewees het, en sal die tyd vir effektiewe getuienis verby wees. Dit wil lyk asof 'n deputategroep nie altyd die mees effek- 
tiewe manier is om profeties teenoor die owerheid te getuig nie, omdat 'n deputategroep nie selfstandige handelingsbevoegdheid het nie, en gebonde is aan opdragte van ' $n$ meerdere vergadering. Dit is daarom noodsaaklik om te begin dink aan alternatiewe maniere waarop die kerk sy profetiese roeping jeens die owerheid kan uitleef.

Die voorstel van hierdie artikel is dat 'n binnelandse Gereformeerde ekumeniese vergadering op die been gebring moet word om wetgewing gereeld op 'n kerklike wyse te monitor. Die voordeel van 'n meer ekumeniese benadering is dat dit die stem van die kerk sterker maak. 'n Meer ekumeniese vergadering kan daartoe lei dat kerke in hul getuienis bo engere kerklike moralistiese aspekte uitstyg (Van der Vyver, 1998b). Die Gereformeerde kerke se getuienis in die verlede toon juis 'n gebrek aan 'n fokus op makro-etiese sake, en 'n oordrewe fokus op mikro-etiese sake soos byvoorbeeld Sondagsonderhouding en dobbelary. Die groot voordeel van so 'n ekumeniese vergadering sal wees dat dit gereeld wetgewing kan monitor en dat dit in die lig van die Skrif en die gereformeerde belydenisskrifte sake kan behandel en afhandel, in teenstelling met 'n deputategroep wat alleen in die lig van 'n welomskrewe opdrag kan handel. So ' $n$ vergadering sal moet toesien dat die beginsels van godsdiensvryheid nie deur wetgewing aangetas word nie, dat wette nie die regte van die inwoners van die land aantas nie, en dat wette onderlinge respek en verdraagsaamheid onder die inwoners van die land bevorder. Die idee van kerklike monitering probeer dan veral aansluiting vind by artikel 185 van die Grondwet, wat ruimte laat vir so 'n ekumeniese liggaam.

Wanneer artikel 28 gehanteer word, kom artikel 30 dadelik ter sprake, aangesien artikel 30 die agenda van meerdere vergaderings bepaal en ook die wyse waarop die agenda behandel moet word. Kerklike sake moet volgens artikel 30 op 'n kerklike wyse gehanteer word. Die uitdrukking "kerklike sake op 'n kerklike wyse" het in die verlede groot probleme geskep in die interpretasie van artikel 30 . Hierdie probleem het ontstaan omdat dié uitdrukking op 'n kerksentriese wyse geïnterpreteer is, ongeag die feit dat die sinodes van 1916 en 1942 nie die begrippe "kerklike sake op 'n kerklike wyse" op 'n eng kerksentriese wyse verstaan het nie. Die rede vir die kerksentriese verstaan van artikel 30 kan deels toegeskryf word aan die Kuyperiaanse invloed met sy klem op die kerk as instituut wat homself net met amptelike bediening mag besig hou, en deels aan politieke voorveronderstellings. Die uitdrukking is in die verlede dikwels gebruik om sensitiewe sake met 'n politieke strekking van die tafels van meerdere vergaderings af te hou, wat weer daartoe gelei het dat die kerk stilgebly het oor magsmisbruik en politieke wandade. So word by die Algemene Sinode van 1984 die volgende 
gerapporteer: "(dit hoort nie) tot die taak van die kerk as instituut om hom tot die owerheid te wend met die doel om allerlei staatkundige en maatskaplike veranderinge in die land tot stand te bring nie" (Algemene Sinode GKSA, Acta, 1984:46).

In 'n beswaarskrif teen besluite wat geneem is in 1984 tydens die sitting van die GES in Chicago, stel die GKSA die volgende beswaar:

The GKSA could not find any material submitted to the RES Chicago 1984 that alleges, not to mention proves, that the GKSA, contrary to their own church ordinance, actively or passively supported Government policy, 'the apartheid system' or an ideology which renders racism or ethnic identity an absolute (GKSA, Acta, 1988: 35).

Die beswaarskrif maak verder die volgende stelling:

In viewing the political situation in South-Africa as an absolute and holding the GKSA responsible for a political situation the RES Chicago 1984 transgressed the principle which implies that ecclesiastical matters must be decided on ecclesiastical grounds. The GKSA express their deepest concern in connection with the non-Scriptural and ideological norms, e.g. 'territorial state' by which the RES Chicago violated its task as an ecclesiastical body in passing judgement on the GKSA and South-African political and economic issues (GKSA, Acta, 1988:236).

Uit bogenoemde aanhalings word dit duidelik dat die GKSA artikel 30 gebruik het om hulself van duidelike uitsprake oor polities-etiese kwessies te weerhou. Die GKSA wou ooreenkomstig artikel 30 nie regeringsbeleid onderskryf nie, en het op grond van artikel 30, waarvolgens die sinode apartheid nie sou kondoneer nie, omdat die kerk homself met kerklike sake besig hou, hulself probeer verontskuldig oor medeverantwoordelikheid aan die sisteem van apartheid. Terselfdertyd wou die GKSA op grond van artikel 30 nie die sisteem van apartheid summier verwerp nie, aangesien die kerk nie politieke sisteme kan voorskryf nie. Dit het gelei tot abstrakte besluite wat breë beginsels betrek het, maar nooit werklik tot die konkrete problematiek deurgedring het nie. Die probleem word duidelik weerspieël uit korrespondensie (vgl. GKSA, Acta, 1988:841-878) wat gevoer is met die Christian Reformed Church (voortaan CRC). In antwoord op die GKSA wat bewyse van die CRC vra oor sinodebesluite wat apartheid sou kondoneer, beskuldig die CRC die GKSA van abstrakte besluite:

What we are concerned about is the abstraction of the statements from the practical situation that exists in the Republic of South-Africa.

The declarations of the GKSA were not formulated in a vacuum.

They arose out of the practical reality of the political, economic and 
social system known as apartheid in South-Africa. As an abstract statement of biblical principles they are commendable, but our critisism is that there is no address to the concrete and practical realities on the basis of these statements (GKSA, Acta, 1988:861862).

Die CRC beskuldig die GKSA verder van "sins of omission" (GKSA, Acta, 1988:870). Ondanks die sinvolle vermanings van die CRC handhaaf die GKSA 'n kerksentriese interpretasie van artikel $30 \mathrm{KO}$ : "Die GKSA kan kragtens KO, artikel 30, nie die regeringstelsel in Suid-Afrika bepaal nie maar spreek gedefinieerde probleme by die owerheid aan" (GKSA, Acta, 1988:877).

'n Kerksentriese verstaan van artikel 30 neem nie die maatskaplike roeping van die kerk in ag nie en laat die kerk in abstraksie verval. Veel eerder moet die koninkryk in die verstaan van die begrippe "kerklike sake op 'n kerklike wyse" as uitgangspunt gebruik word. Kerklike sake is alle religieus-etiese sake wat die beginsels van die koninkryk raak. Dit raak alle gestaltes van Woordverkondiging na binne en buite, en het te doen met Christus se geestelike heerskappy oor die hele wêreld (vgl. Spoelstra, 1989:182).

Kerklike getuienis behoort nie alleen die abstrakte beginsels te stel nie, maar waar nodig en waar moontlik moet die praktiese sonde ook aangetoon word, sodat die kerk nie in abstraksie verval nie. Uit die aard van die saak kan 'n meerdere vergadering homself nie oor elke religieusetiese saak uitspreek nie. Daar is religieus-etiese sake wat op die plaaslike vlak, of die vlak van mindere vergaderinge afgehandel kan word. Hier word dan veral aan mikro-etiese sake gedink. Daar is egter ook religieus-etiese sake wat die gemeenakkoord van kerke, die voortbestaan van die kerkverband en die vreedsame naasbestaan van die inwoners van die land raak. Dit spreek vanself dat meerdere vergaderings veral makro-etiese vraagstukke sal hanteer, waar duidelike en eenvormige getuienis van kerke nodig is. In die nuwe Suid-Afrika sal meerdere vergaderings veral aan die beginsels van 'n regstaat moet aandag gee. Aspekte soos onder andere die volgende moet betrek word om te verhoed dat Suid-Afrika nooit weer 'n totalitêre staatsbestel kry nie: godsdiensvryheid, vryheid van mening en assosiasie, die regte van die inwoners jeens die owerheid, staatsinmenging in private instansies se sake, die gebondenheid van die owerheid aan 'n hoofstuk van fundamentele regte, die onafhanklikheid van die howe. Sake soos armoede, korrupsie, geweld en menseregte is verdere voorbeelde van makroetiese sake. 
Kerklike sake moet op 'n kerklike wyse gehanteer word, wat inhou dat dit primêr om Skrifgefundeerde getuienis en belydenis gaan, en nie om wetgewing of politieke druk nie. Dit is belangrik dat die kerk moet onthou dat dit dikwels binne 'n sekulêre opset werksaam sal moet wees. Kerklike getuienis mag nie in dogmatisme of moralisme verval nie. Die begrip "kerklike wyse" beteken nie dat kerklike uitsprake altyd dogmaties hoef te wees nie. Die kerk sal soms bereid moet wees om die evangelie in konkrete nie-religieuse taal te verwoord, om sodoende effektief te kan getuig. Die taal van die Handves van Regte kan 'n goeie aansluitingspunt vir 'n nie-religieuse vorm van getuienis wees, wat wel reg laat geskied aan die beginsels van die evangelie.

\section{Konkrete riglyne}

Die kerk bevind homself binne 'n nuwe politieke en maatskaplike konteks. Die gevolg is dat die kerk ook sal moet herbesin oor die wyse waarop hy sy profetiese roeping nakom.

\subsection{Besinning oor die wyse waarop die kerk profeties getuig}

Die kerk het sedert 1948-1994 geleef binne 'n politieke bedeling wat sekere Christelike teokratiese elemente bevat het. Die kerk kon daarom ook met die owerheid praat, met die Christelike godsdiens as uitgangspunt. Aan die ander kant het die owerhede van die apartheidsera ook net 'n sekere vorm van Christelikheid bevorder. Hulle was dikwels vyandig teenoor Christelike groeperinge wat die apartheidsbeleid bevraagteken het. Kerke kon hulself nie op die reg beroep indien owerhede hulle mag misbruik het nie.

Die kerk bevind homself egter nou binne 'n nuwe konteks. Die owerheid sien homself as 'n neutrale owerheid wat nie 'n spesifieke godsdiens probeer bevorder nie, met die gevolg dat kerk en owerheid nie meer op 'n gemeenskaplike grondslag met mekaar kan praat nie. Die kerk kan ook nie meer voorkeurbehandeling van die owerheid verwag ten koste van ander godsdienste nie. Die Grondwet is die hoogste wet in die land met die gevolg dat grondwetlike waardes voorkeur geniet bo godsdienstige en kulturele waardes indien die verskillende waardes sou bots. Die Handves van Regte perk die mag van die owerheid in, sodat die kerk nou 'n regskanaal het waarop hy homself kan beroep as die owerheid sy mag sou misbruik.

Daar is veral vier aspekte waaroor die kerk sal moet herbesin in die uitvoering van sy profetiese taak:

- Die strafreg moet nie gebruik word om sosiale euwels te straf nie 
Die GKSA het dikwels in die verlede van die owerheid verwag om moraliteit deur wette te handhaaf. Die sinode van 1982 gee byvoorbeeld aan die deputate vir gesprek met die owerheid opdrag om "aan te dring op wetgewing" om die praktyk van Sondaghandel aan bande te lê (GKSA, Acta, 1982:616). Volgens Van der Vyver (1998b) moet die strafreg nie gebruik word om sosiale euwels te bekamp nie. Onder sosiale euwels word optredes verstaan wat vanuit 'n Christelike oogpunt immoreel sou wees, maar wat nie noodwendig 'n skadelike gevolg vir medelandsburgers inhou nie. In hierdie opsig word gedink aan sosiale euwels soos byvoorbeeld dobbelary en private permissiewe gedrag. Dwang waarborg volgens Van der Vyver (1998b) nie morele kwaliteit nie. As die owerheid die strafreg gebruik om alle sosiale euwels te bekamp, word die staat 'n totalitêre staat wat in die sake van privaatinstansies inmeng. Die owerheid moet die vreedsame naasbestaan van mense bevorder. Daar is ander maniere waarop moraliteit in 'n land gehandhaaf kan word, onder meer deurdat die kerk sy profetiese roeping teenoor die inwoners van die land self nakom.

\section{- Die kerk moet teen dualisme waak}

Die kerk sal daarteen moet waak om nie net aandag te gee aan mikroetiese sake nie, maar ook aan makro-etiese sake soos armoede, sosiaal strukturele etiek en die bewaring van natuurbronne. Die GKSA het in die verlede sterk standpunt ingeneem teen byvoorbeeld Sondagaktiwiteite en dobbelary, maar stilgebly oor armoede, magsmisbruik, onderdrukking en ander makro-etiese sake.

\section{- Die kerk moet 'n gemeenskaplike gespreksbasis met die ower- heid vind}

'n Onderskeid moet getref word tussen getuienis teenoor die owerheid en gesprek met die owerheid. Wanneer die kerk teenoor die owerheid getuig, is ' $n$ gemeenskaplike basis van verstaan nie altyd nodig nie. Die kerk kan bloot deur 'n sinodebesluit 'n bepaalde standpunt wat konsekwensies vir die owerheid het, in die openbaar stel. Die kerk sal in sy gesprek met die owerheid aansluiting moet probeer vind by maatskaplike omstandighede. Die beginsels van Skrif en belydenis sal in nie-religieuse taal verwoord moet word, en konkreet binne die maatskaplike omstandighede toegepas moet word, omdat die owerheid nie vatbaar is vir kerklike dogmas nie. Die Handves van Regte kan hiervoor as 'n belangrike aanknopingspunt dien.

\section{- Christelike politieke partye}

Die gevaar van 'n Christelike politieke party is altyd dat politieke en Christelike beginsels so met mekaar vermeng kan word dat ' $n$ vorm van 
burgerlike godsdiens kan ontstaan. Dit is belangrik dat kerke 'n kritiese distansie teenoor die owerheid moet handhaaf. 'n Ander gevaar van 'n Christelike politieke party is dat dit ander partye aan sekularisme oorlaat. Christene moet verkieslik eerder deel word van die breë politieke proses in die land en nie sy identiteit in 'n Christelike party gaan soek nie.

\subsection{Aspekte waaroor die kerk profeties sal moet getuig}

Suid-Afrika se demokrasie is nog baie jonk. Die gevaar dat Suid-Afrika weer 'n totalitêre staat kan word, is 'n wesenlike gevaar. Die kerk sal daarom as 'n waghond vir die nuwe demokrasie en die regstaat moet optree. Nie die owerheid nie, maar wel die bevolking sal uiteindelik die beginsels van demokrasie en die oppergesag van reg moet bewaar. Die belang van demokrasie, onafhanklike regspraak, gebalanseerde magsuitoefening en menseregte sal deel moet word van die psige van die Suid-Afrikaanse nasie. Hierin het die kerk 'n belangrike rol om te speel, omdat die kerk as instrument van die koninkryk van God na geregtigheid moet soek - ook in die samelewing. Daar is verskeie aspekte waaroor die kerk profeties sal moet getuig:

\section{- Die kerk sal moet getuig teen magsmisbruik deur die owerheid}

'n Koninkryksperspektief laat nie 'n volkome skeiding tussen kerk en staat toe nie. Christus regeer as Kurios oor die hele skepping (vgl. Kolossense 1:15-20). Die kerk moet die owerheid herinner aan sy Godgegewe taak binne die koninkryk van God, want aardse koninkryke mag nie 'n bestaan los van die koninkryk van God voer nie. Die koninkryk van God relativeer aardse koninkryke (Van Wyk, 1992:558). Die taak van die owerheid is om reg en orde te handhaaf en die vreedsame naasbestaan van die burgers onder sy jurisdiksie te verseker. Die owerheid moet as dienaar van God ook geregtigheid in die samelewing bevorder. Die vestiging van 'n politieke stelsel wat geregtigheid waarborg, is 'n wesenlike deel van die taak van die owerheid (Vorster, 1997b:80). Die owerheid ontvang dus nie van God onbeperkte mag nie. 'n Owerheid wat sy mag misbruik, staan in diens van uitbuiting en onderdrukking, en is 'n hindernis in die pad van die koninkryk van geregtigheid. Grondwetlike waarborge teen magsmisbruik alleen is egter nie altyd voldoende nie. Die burgers van die land moet hierdie grondwetlike beginsels verstaan, en die kerk moet as instelling ook as ' $n$ waghond van hierdie beginsels optree, om sodoende te keer dat die owerheid nie sy mag misbruik nie.

Die kerk se taak in dié verband is drieërlei:

- Die kerk het 'n opvoedkundige taak. Kerke moet die inwoners van die land op hulle regte wys. Mense wat nie hulle regte ken nie, kan maklik uitgebuit word en die prooi van magsmisbruik word. 
- Die kerk het die taak van protes. In gevalle van magsmisbruik moet die kerk met die owerheid self praat, omdat ook die owerheid gehoorsaam moet wees aan die wette van die land.

- Die kerk het soms die taak van litigasie. Dit kan gebeur dat die kerke in ekumeniese verband soms wette wat gemaak word, deur howe moet laat toets aan die Grondwet van die land. Die regstaat bied kanale vir die toetsing van wette.

Vir die instandhouding van die Suid-Afrikaanse demokrasie is dit noodsaaklik dat kanale wat die regstaat bied vir die instandhouding van die demokrasie benut moet word. 


\section{- Kerklike monitering van wetgewing moet plaasvind}

Kerklike monitering van wetgewing kan in die toekoms noodsaaklik word. Die voordeel van 'n Gereformeerde ekumeniese vergadering wat wetgewing op 'n gereelde wyse monitor, is dat dit eenvormige gereformeerde getuienis kan gee. Verdeelde getuienis ontneem die profetiese getuienis van kerke sy krag. Ekumeniese perspektiewe kan verder ook verrykend wees vir elke deelnemende kerkverband, en kan tot 'n groter fokus op makro-etiese sake lei. 'n Gereformeerde ekumeniese vergadering kan sake ook, in teenstelling met 'n deputaatskap, behandel en afhandel. Een van die oogmerke van so 'n vergadering behoort te wees om kontak te soek met die verskillende grondwetlike instellings wat ter ondersteuning van die demokrasie ingestel is.

\section{- Die kerk moet 'n kultuur van menseregte help vestig}

Een van die grootste uitdagings vir die kerk is om deur sy prediking en bediening 'n kultuur van menseregte in Suid-Afrika te help vestig. Die hoë misdaadsyfer in Suid-Afrika is 'n bevestiging van die feit dat daar in Suid-Afrika 'n basiese gebrek aan respek vir die regte van ander mense is. Die inwoners van die land sal respek vir lewe en basiese menseregte moet aanleer. Nie net die regte wat mense het nie, maar ook die verantwoordelikhede van mense teenoor mekaar is van groot belang. Die feit dat die mens sekere regte het, impliseer ook dat hy sekere pligte teenoor ander mense het. Die rol van die kerk sal dan wees om veral die pligte wat mense teenoor mekaar het te beklemtoon.

\section{- Die kerk moet rassisme uitroei}

Rassisme bied die potensiaal vir konflik op groot skaal. Kerke sal egter eers rassisme in hul eie geledere moet uitroei, alvorens hulle rassisme in die samelewing uit die weg kan ruim. Die kerk moet predik teen rassisme, profeties getuig daarteen, rassistiese wetgewing grondwetlik beveg, en samewerking met die kommissie vir die beskerming van menseregte probeer soek.

\section{- Die kerk moet 'n eksemplariese gemeenskap van versoening wees}

Die kerk moet as 'n versoende gemeenskap 'n eksemplariese gemeenskap van versoening in die wêreld wees. Dit hou in dat die Christen as 'n versoende in diens van versoening, vrede en vryheid in die wêreld moet staan. 
- Die kerk moet homself beywer vir die instandhouding van die regsisteem in Suid-Afrika

'n Goeie regsisteem is noodsaaklik om 'n Handves van Regte sinvol te laat funksioneer. Die kerk moet homself vir 'n onafhanklike regbank, goeie polisiëring en 'n doeltreffende gevangenisdiens beywer.

\section{- Die kerk moet die vraagstuk van armoede help oplos}

Die kerk kan nie veel doen ten opsigte van die strukturele probleme van die Suid-Afrikaanse ekonomie nie. Die kerk kan hom wel beywer vir 'n regverdige ekonomiese sisteem waarin arm mense nie uitgebuit word nie. Die verskynsel van goedkoop arbeid is deel van die strukturele aard van die Suid-Afrikaanse ekonomie en behoort ook deur kerke aangespreek te word. Die meeste strukturele probleme van die Suid-Afrikaanse ekonomie het egter niks te doen met 'n onregverdige ekonomiese sisteem nie. Die kerk het ook nie die finansiële bronne om werklik 'n verskil te maak nie. Wat die kerk wel kan doen, is om kennis te neem van die etiese oorsake van armoede en dit te probeer oplos. Die kerk sal profeties moet getuig oor verantwoordelike menslike voortplanting, die bewaring van natuurlike bronne, die handhawing van 'n eerlike werksetiek en so meer. 'n Herbesinning oor die kerklike diakonaat en die amp van die diaken is in hierdie verband noodsaaklik.

\section{Slotsom}

Die oorkoepelende navorsingsvraag van hierdie artikel was: Hoe moet die kerk sy profetiese roeping met betrekking tot die owerheid binne die konteks van 'n regstaat uitleef? Die bevinding van hierdie artikel is dat 'n regstaat wat fundamentele regte erken aan die kerk 'n besondere geleentheid bied om sy roeping met betrekking tot die Suid-Afrikaanse owerheid uit te leef. Die kerk kan met die koninkryk van God as uitgangspunt aansluiting vind by die Handves van Regte, deur die regering te herinner aan sy taak om as dienaar van die koninkryk reg en orde te handhaaf. Die uitdaging vir die kerk sal wees om in die toekoms 'n Christelike fundering aan menseregte te gee, en 'n kultuur van menseregte te bevorder.

\section{Bibliografie}

BARTH, K. 1944. Rechtfertigung und Recht. Zürich : Evangelischer Verlag.

BARTH, K. 1946. Christgemeinde und Bürgergemeinde. Zürich : Evangelischer Verlag.

BARTH, K. 1962. Church Dogmatics IV/ III. Edinburgh : Clark.

BRÜNNER, E. \& BARTH, K. 1946. Natural theology: comprising nature and grace. London: The Centenary Press.

CALVYN, J. 1992. Institusie van die Christelike godsdiens 1559. Boek 4. Vertaling deur H.W. Simpson. Potchefstroom : Calvyn Jubileum Boekefonds. 
COETZEE, G. 1995. Human rights - the start of a new culture. RSA Review, 8(2):3040, Jan /Feb.

DE KRUIJF, G.G. 1994. Waakzaam en nuchter: over Christelijke ethiek in een democratie. Baarn : Ten Have.

DU PLOOY, A. LE R. 1991. Enkele bakens in die verhouding tussen kerk en staat met die oog op die ontstaan van die nuwe Suid-Afrikaanse staat. (In Helberg, J.L., red. Kerkwees as getuienis in Suid-Afrika vandag. Potchefstroom : PU vir CHO. p. 104-127.)

DURANDT, J. 1988. Church and state in South-Africa: Karl Barth vs Abraham Kuyper. (In Villa-Vicencio, C., ed. On reading Karl Barth in South-Africa. Grand Rapids, Mich. : Eerdmans. p. 121-139.)

GEREFORMEERDE KERK IN SUID-AFRIKA. 1970. Handelinge van die sewe en dertigste sinodale vergadering van die Gereformeerde Kerk in Suid-Afrika. Potchefstroom : Potch Herald.

GEREFORMEERDE KERK IN SUID-AFRIKA. 1973. Handelinge van die agt en dertigste sinodale vergadering van die Gereformeerde Kerk in Suid-Afrika. Potchefstroom : Potch Herald.

GEREFORMEERDE KERK IN SUID-AFRIKA. 1979. Handelinge van die veertigste sinode te Potchefstroom. Potchefstroom : Potch Herald.

GEREFORMEERDE KERK IN SUID-AFRIKA. 1982. Handelinge van die een en veertigste sinode te Potchefstroom. Potchefstroom : Potch Herald.

GEREFORMEERDE KERKE IN SUID-AFRIKA. 1984. Handelinge van die vierde Algemene Sinode: in sitting byeen te Potchefstroom. Potchefstroom : Administratiewe Buro.

GEREFORMEERDE KERKE IN SUID-AFRIKA. 1988. Handelinge van die drie en veertigste Nasionale Sinode. Potchefstroom : Potch Herald.

GEREFORMEERDE KERKE IN SUID-AFRIKA. 1997. Handelinge van die ses en veertigste Nasionale Sinode te Potchefstroom. Potchefstroom : Potch Herald. GKSA

kyk Gereformeerde Kerke in Suid-Afrika

GRONDWET kyk Suid-Afrika

JONKER, W.D. 1994. Bevrydende waarheid: die karakter van die gereformeerde belydenis. Wellington : Hugenote Uitgewers.

KÜNG, H. 1995. Christianity. The religious situation of our time. London : SCM Press.

KUYPER, A. 1870. Geworteld en gegrond. De kerk als organisme en instituut: intreerede uitgesproken in de Nieuwe kerk te Amsterdam. Amsterdam : De Hoogh.

KUYPER, A. 1909 III. Encyclopedie der heilige Godgeleerdheid. Kampen : Kok.

KUYPER, A. 1932?. De Gemeene Gratie. Deel 1-3. Kampen : Kok.

LEITH, J.H. 1989. John Calvin's doctrine of the Christian life. Louisville, Ky. : Westminster.

LE ROUX, F. 1994. Die beginsels van 'n regstaat. RSA Review/Oorsig, 7(2):56-61, Maart.

MACLEOD, D. 1988. Theocracy. (In Ferguson, S.B. \& Wright, D.F., eds. New Dictionary of Theology. Leicester : Intervarsity Press. p. 677-679.)

NAUTA, D. 1971. Verklaring van de Kerkorde van de Gereformeerde Kerken in Nederland. Kampen : Kok.

POLMAN, A.D.R. s.a. Onze Nederlandsche Geloofsbeijdenis: verklaard uit het verleden geconfronteerd met het heden. Deel. 4. Franeker : Wever. 
RIDDERBOS, H. 1959. Commentaar op het Nieuwe Testament: aan de Romeinen. Kampen : Kok.

RIDDERBOS, H. 1966. Paulus: ontwerp van zijn theologie. Kampen : Kok.

RIDDERBOS, H. 1969. The coming of the kingdom. Philadelphia, Pa. : Presbiterian \& Reformed Publishing Company.

RIENECKER, F. \& ROGERS, C. 1980. Linguistic key of the New Testament. Grand Rapids, Mich. : Zondervan.

SA

kyk Suid-Afrika

SPOELSTRA, B. 1989. Gereformeerde kerkreg en kerkregering: 'n handboek by die Kerkorde. Hammanskraal : HTS.

STRAUSS, P.J. 1993. Op die tweesprong? Die Nederduitse Gereformeerde Kerk oor die tema "kerk en samelewing" in die Kerkorde en Kerk en Samelewing-1990. Bloemfontein : UOVS.

SUID-AFRIKA. 1967. Wet op nasionale onderwysbeleid no 39 van 1967. Pretoria : Staatsdrukker.

SUID-AFRIKA. 1974. Wet op publikasies no 42 van 1974. Pretoria : Staatsdrukker.

SUID-AFRIKA. 1977. Wet op die verbod op die vertoon van rolprente op Sondae en publieke vakansiedae no 16 van 1977. Pretoria : Staatsdrukker.

SUID-AFRIKA. 1979. Wet op onderwys en opleiding no 90 van 1979. Pretoria : Staatsdrukker.

SUID-AFRIKA. 1983. Grondwet van die Republiek van Suid-Afrika no 110, 1983. Pretoria : Departement van Buitelandse Sake en Inligting.

SUID-AFRIKA. 1996. Constitution of the Republic of South-Africa as adopted by the Constitutional Assembly on 8 May 1996 and as amended on 11 October 1996.

VAN DER VYVER, J.D. 1998a. Constitutional perspective of church-state relations in South-Africa. (Referaat gelewer te Salt Lake City by konferensie oor kerk-staatverhoudinge van 4-6 Oktober 1998.) Ongepubliseer. (In besit van outeur).

VAN DER VYVER, J.D. 1998b. Persoonlike onderhoud. Atlanta, Ga. (Aantekeninge in besit van outeur.)

VAN ROOYEN, J.H.P. 1964. Kerk en staat. Utrecht : Universiteit van Utrecht.

VAN WYK, J.H. 1991a. Kerklike getuienis in 'n polities gepolariseerde samelewing. (In Helberg, J.L., red. Kerkwees as getuienis in Suid-Afrika vandag. Potchefstroom : PU vir CHO. p. 172-193.)

VAN WYK, J.H. 1991b. Moraliteit en verantwoordelikheid: opstelle oor politieke etiek. Potchefstroom : PU vir CHO.

VAN WYK, J.H. 1992. Predikant en politiek. In die Skriflig, 26(4):551-562.

VELEMA, WH. 1989. Abraham Kuyper als theoloog: een persoonlike evaluatie na dertig jaar. In die Skriflig, 23 (3):56-71.

VENTER, C.J.H. 1985. Die Pauliniese paranese in Romeine 12-15:13. 'n Eksegetiese studie. Potchefstroom : PU vir CHO. (Th. D. - proefskrif.)

VENTER, C.J.H. 1997. Prediking oor politieke sake: riglyne vanuit Romeine 12-15. In die Skriflig, 31(1, 2):19-33.

VENTER, F. 1995. Die ontstaan van staatkundige stelsels toegepas op die kontemporêre Suid-Afrikaanse staat. Tydskrif vir Geesteswetenskappe, 35(1):128139, Maart.

VENTER, F. 1997. Aspects of the South-African Constitution of 1996: an African democratic and social federal Rechtstaat. Heidelberg Journal of International Law / Zeitschrift für auslandisches öffentliches Recht und Völkerrecht, 57(1):5282. 
VORSTER, J.M. 1993a. Kuyper se ekklesiologie en die interpretasie van "kerklike sake" in artikel 30 van die Kerkorde van die Gereformeerde Kerke van SuidAfrika. In die Skriflig, 27(2):215-229, Junie.

VORSTER J.M. 1993b. Godsdiensvryheid in 'n toekomstige Suid-Afrika in die lig van artikel 36 van die Nederlandse Geloofsbelydenis. In die Skriflig, 27(3):307-321, September.

VORSTER, J.M. 1997a. Is die kerk funksioneel? Gedagtes oor Gereformeerde kerkvernuwing in 'n post-moderne konteks. Potchefstroom : $\mathrm{PU}$ vir $\mathrm{CHO}$.

VORSTER, J.M. 1997b. Teologies-etiese perspektiewe op die 1996-Grondwet van die republiek van Suid-Afrika. In die Skriflig, 31(1 en 2):79-93, Maart / Junie.

VORSTER, J.M. 1998. Calvin and human rights. Ongepubliseerde artikel. (In besit van outeur.)

WENTSEL, B. 1982. De openbaring, het verbond en de apriori's. Dogmatiek deel 2. Kampen : Kok.

\section{Kernwoorde:}

kerk as instituut, Kuyper se siening

kerk as organisme, Kuyper se siening

kerk en staat, verhouding tussen

kerkorde

koninkryk

Kuyper, siening oor algemene en partikuliere genade

neutrale staat

politieke bedeling met teokratiese elemente

profetiese taak van die kerk, Kuyper en Barth

regstaat

\section{Key concepts:}

church as institution, Kuyper's view

church as organism, Kuyper's view

church and government, relation between

church order

constitutional state

kingdom

Kuyper's view, general and particular grace

neutral government

political dispensation with theocratic elements

prophetic task of the church, Kuyper and Barth 